\title{
Financial Capability and Differences in Age and Ethnicity*
}

\author{
Nuradibah MOKHTAR ${ }^{1}$, Mohamad Fazli SABRI ${ }^{2}$, Catherine Soke Fun HO \\ Received: August 01, 2020 Revised: September 06, 2020 Accepted: September 10, 2020
}

\begin{abstract}
The objective of this study is to disclose the effect of socio-demographic characteristics such as, age and ethnicity which is comprised of Malay, Chinese, Indian and Others on four financial capability domains namely planning ahead, managing money, choosing products and staying informed. A closed ended self-administered questionnaire was disseminated to a total of 2000 respondents among four types of groups which consist of FELDA or rural area residents, private sector employees, government sector employees and youth in institutions of higher learning in Malaysia. Those four groups were selected to cover a wide range of Malaysian population. 500 respondents were involved in this study for each types of groups through purposive sampling technique. Analysis of Variance (ANOVA) and analysis via Statistical Package for Social Science (SPSS) was utilized in this study. The results revealed that age has significant effect on planning ahead, managing money, choosing products and staying informed. Whereas, ethnicities were found to have no effect on financial capability except planning ahead domain. It is suggested that more devotion should be placed on research and professional training in building respondents' financial capability. Furthermore, government and non-government organizations should develop a comprehensive approach to intensify their financial capability and upgrade their standards of living especially of financially vulnerable households.
\end{abstract}

Keywords: Financial Capability, Financial Planning, Capital Market, Age, Ethnicity

JEL Classification Code: D10, D12, D14, J16

\section{Introduction}

The world today in in the grip of a widespread fear due to the fear of the invincibility and disastrous effects of

\footnotetext{
*Acknowledgements:

The researchers wish to extend our sincere appreciation to Malaysian Financial Planning Council (MFPC) and the grant provided by Capital Market Development Fund, Securities Commission in funding this research (Vot:6300865). Special thanks also go to those who have directly or indirectly assisted us in the research process: Desmond Chong, Anthony Ang, Chung Kar Yin, Thechinamoorthy Subbiah Chettiar, Thinagaran A/L Moga Dass, Mervin Anthony and Syed Khalil Syed Mahmood in our research committee.

${ }^{1}$ First Author. Researcher, Department of Resource Management \& Consumer Studies, Faculty of Human Ecology, Universiti Putra Malaysia, Malaysia. Email: adib3074@gmail.com

${ }^{2}$ Corresponding Author. Professor, Sustainable Consumption Research Centre of Excellence (SCoRE), Faculty of Human Ecology, Universiti Putra Malaysia, Malaysia [Postal Address: 43400 Serdang, Selangor, Malaysia] Email: fazli@upm.edu.my

${ }^{3}$ Professor, Faculty of Business \& Management, Universiti Teknologi MARA, Malaysia. Email: catherine@uitm.edu.my

(c) Copyright: The Author(s)

This is an Open Access article distributed under the terms of the Creative Commons Attribution Non-Commercial License (https://creativecommons.org/licenses/by-nc/4.0/) which permits unrestricted non-commercial use, distribution, and reproduction in any medium, provided the original work is properly cited.
}

Coronavirus pandemic (COVID-19). Its sudden emergence in late 2019 in China and rapid spread around the globe has become the most challenging crisis ever as termed by the United Nations (UN). Within three months, more than 1 million people in 180 countries were tested positive for the viral illness and at least 50 thousand have died (Rasheed, 2020). In addition to the lost and affected lives, global economic and social toll of this pandemic has become extraordinary never witnessed before. This has resulted in the financial crisis globally and resulting in a massive volatility and market ambiguity.

The crisis has created a condition of helplessness and has amply displayed the delicateness of an integrated world economy, the supply chain has crumbled and has become unstable and consequently the world economy has been pushed towards recession or even depression. Furthermore, economic and business threats from the coronavirus outbreak continues as travel bans have been put on millions of people and quarantine measures have been placed on entire populations in many countries. Not only that, loss of revenue and disrupted supply chain has added more burden to businesses because the recession threatens nearly all countries. As a result, financial anxiety has become a sort of second pandemic along with COVID - 19 health pandemic (Shiller, 2020). 
Generally, people assume that financial anxiety is a direct by-product of COVID - 19 crisis which is a logical reaction arising from the situation resulting from the pandemic. However, anxiety is not part of a logical explanation, it is when people are emotionally upset due to a tragic event that they react with fear though at that time there is no reason to feel so (Shiller, 2020). Financial anxiety can be handled with one's financial capability. Individuals who possess knowledge to oversee situations and are responsible for his or her finances, would not react with fear when a tragic event takes place. For those who are financially capable, have the ability to apply appropriate financial knowledge and at the same time take effective financial judgement are able to sustain their economic well-being.

Financial capability is increasingly becoming a priority for policymakers in both developed and developing countries, due to its recognition as a contributor towards effective functioning of financial markets, financial inclusion and financial stability. According to Khan (2008), being financially capable is the basic requirement for financial inclusion. Enhancing one's financial capability is a good way of responding to those who suffer from the ill-effects of financial exclusion and will ensure they are able to make better decisions about their personal finance in the future. Financial capability can be enhanced through financial literacy. It was found that higher financial literacy leads to better participation in financial market (Nguyen \& Nguyen, 2020) and money management (Abdullah, Fazli \& Arif, 2019; Zulfaris, Mustafa, Mahussin, Alam, \& Daud, 2020). This indicated that financial capability can assist individuals to achieve their life goals. In Malaysia, Credit Counselling and Debt Management (AKPK) survey disclosed that 1 out of 3 Malaysians are uncomfortable with their financial knowledge (Tan, 2019).

Whilst, slightly more than half of the population (52\%) admitted that they experienced difficulties to prepare RM1,000 for emergencies. In terms of preparedness and sustainability for loses of one's source of income, only 24 percent could survive for up to 3 months and 10 percent were confident that they could last for 6 months. As for retirement planning, 68 percent of retiree that retire by 55 years old have less than RM240,000 in their Employee Provident Fund (EPF) account. Moreover, 70 percent of them who withdrew money from the EPF said that it lasted for 5-10 years. In addition, Yusof (2019) mentioned that among three major ethnicities in Malaysia, the Malays and the Indians are more financially fragile compared to the Chinese. This is supported by Alidaniah, Ahmad, Noor and Moi (2017) who found that Malay and Indian were expending money in a luxurious manner than compared to the Chinese. Thus, low financial capability is a national challenge that can affect society in many ways.
In line with that, Malaysia has launched the National Strategy for Financial Literacy 2019 - 2023 which a comprehensive plan for 5 years that aims to enhance the financial literacy, promote responsible behaviour and rational attitude among Malaysians in order to improve their financial well-being. Thus, this study aims to examine the effect of socio-demographic characteristics on financial capability.

\section{Literature Review}

\subsection{Financial Capability}

Taylor (2011) defined financial capability as an individual's ability to manage and control their finances. Financial capability is an internal capacity to act according to one's best financial interest despite their socioeconomic and environmental conditions (The World Bank, 2013). It refers to the ability of applying appropriate financial knowledge and perform necessary financial behaviour to attain financial goals and at the same time enhance financial well-being (Xiao, 2016). According to Atkinson, McKay, Collard, and Kempson (2006) and Taylor (2011), financial capability can be measured in various ways. It consists of financial literacy, behaviour, perceived financial capability (Xiao, Chen, \& Chen, 2014), motivations, attitudes, and confidence (Lowies, Helliar, Lunshington, \& Whait, 2019).

Therefore, Financial Industry Regulatory Authority (FINRA) (2009) and Organization for Economic Cooperation and Development (OECD) (2005) has categorised financial capability into four key components which are managing money, staying informed, planning ahead and choosing products. They believed that financial capability requires not only financial literacy, but also access to appropriate financial products. Skills, motivation, knowledge and confidence solely could not represent financial capability without one's ability to avail the beneficial financial products offered by financial institutions. Financial capability research seeks to understand as well as to improve individual's financial decision making (Xiao, 2016). Johnson and Sherraden (2007) mentioned that financial capability, ability and opportunity contribute towards one's financial well-being.

Financial capability has been linked with variety of constructs such as money attitude, financial strain (Sabri, Abdullah, Zenhendel, \& Ahmad, 2018), financial education (Xiao \& O’Neill, 2016), distress (Scott, Vu, Cheng, \& Gibson, 2018), financial satisfaction (Xiao \& O'Neill, 2018) and social relationships (Ranta, Punamaki, Chow, \& Salmela-Aro, 2019). However, social demographic factors also have been associated with financial capability in previous studies (Bharucha, 2017; Jeyaram 
Nuradibah MOKHTAR, Mohamad Fazli SABRI, Catherine Soke Fun HO /

\& Mustapha, 2015; Loke, 2017; Ooko, 2017; Wingfield, 2016). Wide range of financial capability relationship has been used to link the gap of studies and to the available body of knowledge. Age and ethnicities are among the demographic variables that can be used as an indicator to identify vulnerable groups of population whereby targeted intervention can be designed.

\subsection{Ethnicity}

There is a gap among race towards financial capability (Al - Bahrani, Weathers, \& Patel, 2019). This is because, Al - Bahrani et al. (2019) concluded that insufficient parental guidance or even poor access to financial literacy education affected one's financial capability. This can be seen when they divulged financial literacy scores for minorities which are lower than Whites. They also added that Whites were more likely to participate in financial literacy education. In line with that, Wingfield (2016) also disclosed that Black students are more likely to score below average than White students. Moreover, Financial Industry Regulatory Authority (FINRA) has conducted a survey in 2018 which mentioned that Black community were more financially illiterate among American adults (Banks, 2020). Despite that, American Sociology of Race and Ethnicity stated that Blacks spend on average is less than the Whites. Therefore, they believed that it is not because of spending habit or lack of financial literacy, but it due to the racial wealth gap. Income inequality has made Black families income half less than White families. Parallel to that, Do, Mai, Nguyen, Pham, Le, and Vu (2020) stated that minority ethnic community has mediocre academic background. Hence, they primarily seek employment in low-skilled and simple jobs that are unstable, underpaid and unsustainable.

While, Nam, Huang, and Lee (2016) studied ethnic differences among Older Asian Immigrants mentioned that ethnicities are insignificant towards financial capability. They suggested that appropriate measurement based on culture should be develop in order to measure financial capability. As for the Malaysian context, Jeyaram and Mustapha (2015) found that among the main three ethnicities, Chinese possessed higher financial literacy compare to other ethnicities. In the recent years, researchers such as Alidaniah et al. (2017), Loke (2017), Mokhtar, Sabri, Catherine, and Thinagaran (2018) and Yusof, Rokis, and Jusoh (2015) also divulged that Chinese have a better financial capability and they have positive responsible behaviour in personal finances among all ethnicities. In addition, Loke (2017) found that Chinese have 8.5 percent lower probability of poor financial behaviour and 6.8 percent higher good financial behavior compared to people of other ethnicities.

\subsection{Age}

Various age groups may lead to different results of financial capability. This can be supported with Dewees and Mottola (2017) study whcih discovered that financial capability among American Indians or Alaska Natives (AIAN) community varies across age groups. Xiao, Chen, and Sun (2014) and Xiao (2016) and Xiao, Chen, and Sun (2015) agreed that as individual increased in age, their financial capability also increased with their age. This indicated that financial capability has a positive association with age. They also found that young adults particularly between 18 to 24 years had the lowest perceived financial capability. In line with that, Lowies et al. (2019) reported that older people have higher financial capability. They believed as people aged, they encountered lot of knowledge and experience that helped them in making better financial decisions.

Despite that, Dewees and Mottola (2017) found that age differences are unclear. They revealed that financial literacy levels are low for the 18 to 34 years old age group which made them more likely to use alternative financial services. For example, only 22 percent of 18 to 34 years olds are considered highly financially literate, compared to 32 percent for 35 to 54 years old age group and 28 percent for those above 55 years old. Dewees and Mottola (2017) also believed that younger groups might have greater financial information due to the media exposure. This can be supported with Lusardi and Oggero (2017) divulged that financial literacy among 15 to 34 years old age group increased as their usage of internet increased.

\section{Methodology}

A total of 2000 respondents of four different groups were involved in this study via purposive sampling technique. It consists of public sector employees, SME/private sector employees/general public, FELDA/rural area residents and youths in higher learning institutions. These groups cover wide scope of Malaysian population outcome in order to be generalised to the overall Malaysian population. A selfadministered of close ended questionnaire was distributed to the respondents with 40 respondents participated in the pilot study. Pilot study was employed to validate the appropriateness of the research instruments in a preliminary stage. Hence, it guides researchers to make amendments to enhance the clarity, reliability and accuracy of the questionnaire. Parallel to that, instrument's Cronbach Alpha were above 0.7 which was recommended by Pallant (2020), indicated the reliability of the instruments.

In the questionnaire, two major sections were prepared. Demographic and socioeconomic status of the respondents 
were acquired in the first section whilst respondents' financial capability in second section. Twenty statement regarding financial capability were attained from the respondents which was covered by four different domains. It encompassed of managing money, planning ahead, selection of product and staying informed. Each domain can be represented by five questions that respondents required to rate in their responses according to the given Likert scale. These instruments were adopted and adapted from the Scottish Household Survey, British Household Panel Survey and the Central Bank of Malaysia's Survey on Financial Literacy of Malaysian Adults.

\subsection{Analysis}

Statistical Package for Social Science version 22.0 (SPSS) was used to examine respondents' socio-demographic and financial capability. Furthermore, the subsequent statistical tests were applied for further analysis.

\subsubsection{Analysis of Variance (ANOVA)}

One-way analysis of variance or ANOVA was conducted to distinguish mean scores of more than two groups. Parallel to its name, ANOVA compares the variance (variability in scores) between the different groups with the variability within each of the groups (Pallant, 2020). Similar with t-test, Levene's Test of variances homogeneity was also examined to identify weather the variance in each groups' scores are similar or not (Pallant, 2020).

\section{Results and Discussion}

\subsection{Socio-demographic}

The information on socio - demographics of the respondents can be seen in Table 1. Higher percentage $(54 \%)$ of the respondents were female. This is contradicted with the national gender ratio population which indicates that there is more population than the female population. (Department of Statistics Malaysia, 2019). Among 2000 respondents, the sample consisted of 55.3 percent married individuals and 44.7 percent single. This study represented 64 percent of the sample who were Malay, 27.5 percent were Chinese, 5.9 percent were Indian and 2.2 percent were from other ethnicities. Moreover, slightly more than half of the respondents $(57 \%)$ had monthly income of less than RM3, 000 which indicated that they are in the B40 category. Whereas, respondents with monthly income of RM3,000 until RM3,999 comprised of 25.5 percent; RM5,000 until RM5,999 consists 9.4 percent; RM7,000 until RM8,999 comprised 3.3 percent; and above RM9,000 comprised only 4.9 percent (see Table 1).
Table 1: Profile of Respondents

\begin{tabular}{|c|c|}
\hline Socio demographic & $\mathbf{N}(\%)$ \\
\hline \multicolumn{2}{|l|}{ Gender } \\
\hline Female & $1080(54)$ \\
\hline Male & $920(46)$ \\
\hline \multicolumn{2}{|l|}{ Marital Status } \\
\hline Married & $1106(55.3)$ \\
\hline Single & $894(44.7)$ \\
\hline \multicolumn{2}{|l|}{ Ethnicity } \\
\hline Malay & $1280(64)$ \\
\hline Chinese & $558(27.9)$ \\
\hline Indian & $118(5.9)$ \\
\hline Others & $44(2.2)$ \\
\hline \multicolumn{2}{|l|}{ Income (RM) } \\
\hline$<3000$ & $1140(57)$ \\
\hline $3000-4999$ & $510(25.5)$ \\
\hline $5000-6999$ & $188(9.4)$ \\
\hline $7000-8999$ & $66(3.3)$ \\
\hline$>9000$ & $98(4.9)$ \\
\hline \multicolumn{2}{|l|}{ Age (years old) } \\
\hline$<20$ & $202(10.1)$ \\
\hline $20-29$ & $634(31.7)$ \\
\hline $30-39$ & $494(24.7)$ \\
\hline $40-49$ & $306(15.3)$ \\
\hline$>50$ & $368(18.4)$ \\
\hline \multicolumn{2}{|l|}{ Education Level } \\
\hline Primary & $80(4)$ \\
\hline Secondary & $1104(55.2)$ \\
\hline Tertiary & $816(40.8)$ \\
\hline \multicolumn{2}{|l|}{ Monthly Saving (RM) } \\
\hline $0 \%$ & $218(10.9)$ \\
\hline $1-<10 \%$ & $1106(55.3)$ \\
\hline $10-<20 \%$ & $446(22.3)$ \\
\hline$>20 \%$ & $192(9.6)$ \\
\hline \multicolumn{2}{|l|}{ Income Adequacy } \\
\hline Not sufficient & $248(12.4)$ \\
\hline Enough for basic needs & $944(47.2)$ \\
\hline Enough for most things & $472(23.6)$ \\
\hline Enough \& can save money & $338(16.9)$ \\
\hline \multicolumn{2}{|l|}{ Financial Status } \\
\hline Asset $<$ Debt & $720(36)$ \\
\hline Asset = Debt & $440(22)$ \\
\hline Asset $>$ Debt & $840(42)$ \\
\hline
\end{tabular}


Moreover, majority of the respondents $(31.7 \%)$ were in the 20 - 29 years old of age group, followed by 24.7 percent who were between the ages of 30-39 years old. Those who were aged above 50 years comprised 18.4 percent; 40-49 years old with 15.3 percent; and those under 20 years of age comprised 10 percent. Parallel with Malaysia age structure indicated that population from 15 to 64 years old (working age) increased to 70 percent in 2019 compared to previous year (Department of Statistics Malaysia, 2019). 96 percent had either secondary or tertiary education while only four percent had only primary school education.

In terms of the savings proportion from monthly income, 55.3 percent of the respondents saved less than 10 percent of their monthly income while about 11 percent did not save at all. This is indeed worrying as respondents seemed not to feel the need to save nor had the ability to save. In line with the higher percentage of the respondents from B40 category, it is understandable for their difficulties to save due to their cash availability. On the other hand, their monthly income was utilized to support their day-to-day life. Parallel to the depressed wages growth nowadays, 47.2 percent of respondent's income was able to serve just their basic needs. While, 12.4 percent even stated that their income was not sufficient to meet their basic needs. In terms of financial status, 42 percent of the respondents had more assets than debt whilst 36 percent had more debts than assets. It is important to note even though majority of the respondents are in the assets more than debt group, the assets less than debt are closely following behind. It shows that a large number of the respondents had more debt than they should have. Despite that, 22 percent of respondents had a somewhat equal amount of debts and assets.

\subsection{Managing Money}

Result in Table 2 shows that 70 percent of the respondents agreed that they made plans for their expenses and were able to pay their bills on time. This indicates that respondents planned before they spent in order to be able to pay their bills on time. This indicated that they are practicing a good financial management. Parallel to that, a majority of them agreed that they practised financial behaviour such as reviewing and evaluating their expenses (65\%), set aside money for unexpected expenses $(65 \%)$ and achieved financial goals $(62 \%)$. Respondents were aware that by reviewing and evaluating their expenses including regularly setting aside some money for emergency can help them to achieve their financial goals. In general, they are financially capable in managing their money. (See Table 2)

\subsubsection{Managing Money by Ethnic}

An analysis was conducted to analyse the impact of ethnicity on respondents' money management. Participants were divided into four groups according to their ethnicity (Group 1: Malay; Group 2: Chinese; Group 3: Indian; Group 4: Others). There was no statistically significant difference at the $\mathrm{p}<.05$ level in managing money scores for the four ethic groups: $F(3,1989)=0.73, p=0.55$. It can be supported by the post-hoc comparisons using the Tukey HSD indicated the mean score for Group $1(\mathrm{M}=19.40, \mathrm{SD}=3.92) \mathrm{did}$ not contradict significantly from either Group 2 or 3 or 4 . Parallel with Group $2(\mathrm{M}=3.81, \mathrm{SD}=3.81)$ did not diversify significantly from either Group 1 or 3 or 4 . As well as Group $3(\mathrm{M}=19.29, \mathrm{SD}=4.14)$, did not vary significantly from either Group 1 or 2 or 4 . Small and approximately similar mean differences were the possible factors that affected the insignificant results. Therefore, the hypothesis was rejected.

According to the previous literature, a relationship is observed between financial capability and ethnicity. However, financial capability could be summarized using its four domains (Keeney \& O'Donnell, 2009). The behaviours of those four domains might be vary in significance and hence, non-significant result on the relationship between managing money and ethnicity of the Malaysian people could be accepted.

Table 2: Financial capability - Managing money

\begin{tabular}{|c|c|c|c|}
\hline \multirow[t]{2}{*}{ Statement } & D & $\mathbf{N}$ & A \\
\hline & $\mathbf{N}(\%)$ & $\mathbf{N}(\%)$ & $\mathbf{N}(\%)$ \\
\hline \multicolumn{4}{|l|}{ Managing money } \\
\hline I make plans for my expenses. & $143(7.1)$ & $452(22.6)$ & $1405(70.3)$ \\
\hline I pay my bills on time. & $172(8.6)$ & $455(21.0)$ & $1373(70.4)$ \\
\hline I review and evaluate my expenses. & $177(5.5)$ & $525(29.6)$ & $1298(64.9)$ \\
\hline I regularly set money aside for possible unexpected expenses. & $186(5.2)$ & $515(29.8)$ & $1299(65.0)$ \\
\hline I set specific financial goals and strive to achieve them. & $200(10.0)$ & $555(27.8)$ & $1245(62.2)$ \\
\hline
\end{tabular}

Notes: $D=$ Disagree; $N=$ Neutral; $A=$ Agree 
$\boldsymbol{H}_{I}:$ There is a significant difference in managing money with ethnicity

\subsubsection{Managing Money by Age}

Besides that, a test was used to examine the impact of respondents' age on managing money. Participants were divided into five groups according to their age (Group 1: below 20 years; Group 2: 20-29 years; Group 3: 3039 years; Group 4: 40-49 years; Group 5: 50 and above). There was a statistically significant difference at the $p$ $<.05$ level in managing money scores for all age groups: $\mathrm{F}(4,1995)=10.41, \mathrm{p}=0.00$. In line with that, post-hoc test showed that the mean score for Group $5(M=20.42$, $\mathrm{SD}=3.98)$ was significantly different from Group 1 $(\mathrm{M}=18.77, \mathrm{SD}=3.71)$, Group $2(\mathrm{M}=18.91, \mathrm{SD}=3.69)$, Group $3(\mathrm{M}=19.33, \mathrm{SD}=4.06)$ and Group $4(\mathrm{M}=19.12$, $\mathrm{SD}=3.90$ ). Respondents by the age of 50 years old and above had gained experiences beforehand from the rest of the groups when it comes to managing money. Hence, they handle their money differently than the others. On the other hand, there is no significant difference with the rest of the groups with each other. Therefore, the hypothesis failed to reject and the results are the blue print of the previous literature.

\section{$\boldsymbol{H}_{2}:$ There is a significant difference in managing money} with age

\subsection{Planning Ahead}

In terms of planning ahead as shown in Table 3, 32 percent of the respondents preferred to live well at the moment rather than planning for the retirement. On the other hand, a little more than half of the respondents (52\%) confessed that they made adequate plan for unexpected expenses. Moreover, 60 percent of the respondents admitted that they made financial plan for retirement. Furthermore, 55 percent of them believed they will be able to live comfortably after retirement. Apart from planning for emergency and retirement, more than three quarter of the respondents $(80 \%)$ believed that it is vital to have their own savings. This reflects that Malaysians are aware of their finances by planning ahead, but there is a small group that lacks financial knowledge regarding the benefit in delaying instant gratification in a long run (see Table 3).

\subsubsection{Planning Ahead by Ethnic}

Additionally, the impact of ethnicity towards planning ahead was conducted. Participants were divided into four groups accordingly (Group 1: Malay; Group 2: Chinese; Group 3: Indian; Group 4: Others). There was statistically significant difference at the $\mathrm{p}<.05$ level in planning ahead scores for four ethic groups: $\mathrm{F}(3,1989)=11.27, \mathrm{p}=0.00$. Post-hoc test showed that the mean score for Group 1 (M $=18.17, \mathrm{SD}=3.42)$ differ significantly from Group $2(\mathrm{M}$ $=17.32, \mathrm{SD}=3.11)$ and Group $3(\mathrm{M}=16.96, \mathrm{SD}=3.53)$. Nonetheless, Group 2 did not differ significantly from either Group 1 or 3 or 4 . Akin with Group 3 and Group 4 did not significantly different from other groups. As the three main ethnicities in Malaysia with diverse culture and background, it was discovered that each ethnic community has financial capability to plan ahead differently. Therefore, the hypothesis was failed to reject and the result is agreed with the previous scholars.

$\boldsymbol{H}_{3}:$ There is a significant difference in planning ahead with ethnicity.

Table 3: Planning ahead

\begin{tabular}{|l|c|c|c|}
\hline \multirow{2}{*}{ Statement } & D & N & A \\
\cline { 2 - 4 } & N (\%) & N (\%) & N (\%) \\
\hline Planning Ahead & $239(12.0)$ & $712(35.6)$ & $1049(52.4)$ \\
\hline $\begin{array}{l}\text { I make adequate provision for unexpected expenses (shrinking } \\
\text { income). }\end{array}$ & $287(14.4)$ & $512(25.6)$ & $1201(60.0)$ \\
\hline I make financial provision for retirement. & $791(40.0)$ & $569(28.4)$ & $640(31.6)$ \\
\hline $\begin{array}{l}\text { I prefer to have a good standard of living today than planning for } \\
\text { retirement. }\end{array}$ & $340(17.0)$ & $561(28.1)$ & $1099(54.9)$ \\
\hline $\begin{array}{l}\text { Household income after retirement is able to guarantee a more } \\
\text { comfortable living standard. }\end{array}$ & $112(5.6)$ & $295(14.8)$ & $1593(79.6)$ \\
\hline $\begin{array}{l}\text { Apart from contributing in pension funds, it is important for me to make } \\
\text { my own savings. }\end{array}$ & & & \\
\hline
\end{tabular}

Notes: $D=$ Disagree; $N=$ Neutral; $A=$ Agree 
Nuradibah MOKHTAR, Mohamad Fazli SABRI, Catherine Soke Fun HO /

\subsubsection{Planning Ahead by Age}

Impact of age on planning ahead was identified in this study. Participants were divided into five age groups (Group 1: below 20 years; Group 2: 20-29 years; Group 3: 30-39 years; Group 4: 40-49 years; Group 5: 50 and above). Result disclosed that there was a statistically significant difference at the $\mathrm{p}<.05$ level in planning ahead scores for the five age groups: $\mathrm{F}(4,1995)=26.10, \mathrm{p}=0.00$. Based on post-hoc test, it showed that the mean score for Group $5(\mathrm{M}=19.28$, $\mathrm{SD}=3.60)$ was significantly different from Group $1(\mathrm{M}=$ 17.49, $\mathrm{SD}=3.28)$, Group $2(\mathrm{M}=17.11, \mathrm{SD}=3.19)$, Group $3(\mathrm{M}=17.97, \mathrm{SD}=3.25)$ and Group $4(\mathrm{M}=17.72, \mathrm{SD}=$ $3.13)$. Despite the age gap of 10 years, respondents in Group 2 planned ahead differently compared to the Group 3. This can be supported when Group 2 was also found significantly different from Group 3. Therefore, the hypothesis failed to reject and the results proved the previous findings.

\subsection{Choosing Product}

Among 5 questions that were asked to the respondents, 3 questions indicated respondents feel confident in themselves when choosing a product. Table 4 displayed 71 percent of the respondents considered several products/loans/policies/ accounts from different providers before making a decision. Moreover, majority of the respondents (69\%) thoroughly read the terms and conditions beforehand and compared features and prices of the product rather than solely depending on the brand image when choosing a product $(68 \%)$. In line with that, only 40 percent of the respondents believed in financial planners and acknowledged what they were recommended. Nevertheless, only 33 percent respondents admitted that they understand the various financial products needed without having to consult a financial adviser/planner. Despite the fact that they analysed, read and compared the product, they still felt that they were still not financially capable in terms of choosing a product. (See Table 4)

$\boldsymbol{H}_{4}$ : There is a significant difference in planning ahead with age.

\subsubsection{Choosing Product by ethnic}

Then, participants were divided into four ethnic groups (Group 1: Malay; Group 2: Chinese; Group 3: Indian; Group 4: Others) to inspect the influence on choosing a product. Results indicated were not statistically significant difference at the $\mathrm{p}<.05$ level in choosing product scores: $\mathrm{F}(3,1989)=3.48, \mathrm{p}=0.015$. Post-hoc test revealed that the mean score for Group $2(\mathrm{M}=17.82, \mathrm{SD}=3.10)$ did not differ significantly from Group $1(\mathrm{M}=18.18, \mathrm{SD}=3.35)$, Group $3(\mathrm{M}=17.54, \mathrm{SD}=3.75)$ and Group $4(\mathrm{M}=18.91$, $\mathrm{SD}=3.22$ ). Moreover, Group 1, Group 3 and Group 4 did not differ significantly among each other. Therefore, the hypothesis was rejected.

Despite different ethnicities, it does not influence an individual on how to choose a product in Malaysia due to the fact that it is a multinational country that has integrated various different cultures. Furthermore, whatever the ethnic group, all individuals of a country are willing to achieve a higher level of financial well-being without considering their ethnicity. Therefore, the results of the study for Malaysian context could be accepted.

$\boldsymbol{H}_{5}:$ There is a significant difference in choosing products with ethnicity

Table 4: Choosing financial products

\begin{tabular}{|c|c|c|c|}
\hline \multirow{2}{*}{ Statement } & D & $\mathbf{N}$ & A \\
\hline & $\mathbf{N}(\%)$ & $\mathbf{N}(\%)$ & $\mathbf{N}(\%)$ \\
\hline \multicolumn{4}{|l|}{ Choosing product } \\
\hline $\begin{array}{l}\text { I consider several products/loans/policies/accounts from different } \\
\text { providers before making my decision. }\end{array}$ & $149(5.3)$ & $478(23.9)$ & $1373(70.8)$ \\
\hline I read the terms and conditions in detail before agreeing / signing. & $194(9.7)$ & $423(21.2)$ & $1383(69.1)$ \\
\hline $\begin{array}{l}\text { I understand the various financial products that I need without } \\
\text { having to consult a financial adviser/planner. }\end{array}$ & $606(30.3)$ & $734(36.7)$ & $660(33.0)$ \\
\hline I believe financial planners and accept what they recommend. & $376(18.8)$ & $820(41.0)$ & $804(40.2)$ \\
\hline $\begin{array}{l}\text { I compare products in terms of features and price rather than make } \\
\text { a choice based on the brand image. }\end{array}$ & $166(8.3)$ & $475(23.8)$ & $1359(67.9)$ \\
\hline
\end{tabular}

Notes: $D=$ Disagree; $N=$ Neutral; $A=$ Agree 
Table 5: Staying informed

\begin{tabular}{|l|c|c|c|}
\hline \multirow{2}{*}{ Statement } & D & N & A \\
\cline { 2 - 4 } & N (\%) & N (\%) & N (\%) \\
\hline Staying informed & & & \\
\hline $\begin{array}{l}\text { I regularly monitor financial indicators such as changes in the housing } \\
\text { market, stock market and interest rates. }\end{array}$ & $338(16.9)$ & $737(36.9)$ & $925(46.2)$ \\
\hline I actively seek financial information through professional advice. & $454(22.7)$ & $751(37.6)$ & $795(39.7)$ \\
\hline I frequently keep up to date with financial products. & $364(18.2)$ & $733(36.7)$ & $903(45.1)$ \\
\hline $\begin{array}{l}\text { I am always interested to learn and make comparisons of financial } \\
\text { services offered. }\end{array}$ & $245(12.3)$ & $638(31.9)$ & $1117(55.8)$ \\
\hline $\begin{array}{l}\text { I would like to know more about financial issues and learn how to interpret } \\
\text { the information. }\end{array}$ & $159(8.0)$ & $526(26.3)$ & $\begin{array}{c}1315 \\
(65.7)\end{array}$ \\
\hline
\end{tabular}

Notes: $D=$ Disagree; $N=$ Neutral; $A=$ Agree

\subsubsection{Choosing Product by age}

An ANOVA analysis was used to observe the impact of age on choosing product. Results unveiled showed that there was a statistically significant difference at the $p<.05$ level in choosing product scores: $\mathrm{F}(4,1995)=2.75, \mathrm{p}=0.027$. According to the mean score for Group $5(\mathrm{M}=18.48, \mathrm{SD}=$ 3.77) was significantly different from Group $1(\mathrm{M}=17.55$, $\mathrm{SD}=3.29)$. Generation gap has emerged between these age groups as a result of the fact that they were born in a different era which are baby boomers and millennia respectively. Therefore, different exposures have an effect on how they choose their product. Nevertheless, the rest of the groups were found to not significantly differ from each other. Therefore, the hypothesis failed to reject and the results give same conclusions as same as previous literature.

$\boldsymbol{H}_{6}:$ There is a significant difference in choosing products with age

\subsection{Staying Informed}

The data in this section demonstrates that less than half of the respondents regularly monitored financial indicators $(46 \%)$, sought information via professional advice (40\%) and frequently kept themselves up-to-date with available financial products $(45 \%)$ (Table 5). Conversely, slightly more than half of the respondents' were keen to learn and make comparison of the offered services $(56 \%)$ and were interested to know more about financial issues and interpret it (66\%). This shows that respondents were more attracted with personal finance rather than financial market which could enhance their capability in finances. In order to stay informed, one must frequently monitor financial indicators which are up-to-date with information about available financial products and at the same time should seek information from professionals. By doing so, respondents were able to learn effectively about available financial services and interpret it in a realistic and personal manner (see Table 5).

\subsubsection{Staying Informed by Ethnic}

Result revealed that there was statistically significant difference at the $\mathrm{p}<.05$ level: $\mathrm{F}(3,1989)=2.82, \mathrm{p}=0.038$. Tukey test indicated that the mean score for Group 3 (M $=16.80, \mathrm{SD}=4.16)$ did not contradict significantly with Group $4(\mathrm{M}=18.72, \mathrm{SD}=4.31)$. Parallel with Group $1(\mathrm{M}=$ $17.49, \mathrm{SD}=4.21)$ did not diversify significantly from either Group 2 or 3 or 4 . Similar with Group $2(\mathrm{M}=17.71, \mathrm{SD}=$ 3.91) did not vary significantly from either Group 1 or 2 or 3 . Therefore, the hypothesis was rejected.

The financial capability is dependent on four of its domains and their behaviors vary (Keeney \& O'Donnell, 2009). Therefore, even though financial capability has a relationship with ethnicity, the domain of staying informed has not a correlation with the ethnic groups. Furthermore, according to the results of this study the relationship between staying informed and ethnicity is not significant and it reveals that different background and culture did not have an impact on being staying informed.

$\boldsymbol{H}_{7}:$ There is a significant difference in staying informed with ethnicity

\subsubsection{Staying Informed by Age}

Finally, result divulged that there was a statistically significant difference at the $\mathrm{p}<.05$ level for the age groups: $\mathrm{F}(4,1995)=10.61, \mathrm{p}=0.00$. Post-hoc test or Tukey HSD test showed that the mean score for Group $5(\mathrm{M}=18.73$, $\mathrm{SD}=4.36)$ was significantly different from Group $1(\mathrm{M}=$ 
Nuradibah MOKHTAR, Mohamad Fazli SABRI, Catherine Soke Fun HO /

Journal of Asian Finance, Economics and Business Vol 7 No 10 (2020) 1081-1091

$16.89, \mathrm{SD}=3.80)$, Group $2(\mathrm{M}=17.13, \mathrm{SD}=3.84)$, Group $3(\mathrm{M}=17.50, \mathrm{SD}=4.21)$ and Group $4(\mathrm{M}=17.46, \mathrm{SD}=$ 4.24). Conversely, there was no significant difference with the rest of the groups with each other. Results disclosed that an older group being staying informed has a significantly different than the rest of the groups. Variety of knowledge and exposure have made older groups to be differently financially capable than others. Therefore, the hypothesis failed to reject and the results are matched with the previous findings.

$\boldsymbol{H}_{8}:$ There is a significant difference in staying informed with age.

\section{Conclusions}

This study had profiled the socio-economic i.e. ethnicities and age and financial capability among Malaysians. The population for this study consisted of 2000 Malaysians from four distinctive groups that was chosen through purposive sampling technique. Generally, Malaysians are financially capable in managing their money. However, respondents revealed lack in financial capability when they preferred to have a good standard of living today than planning for retirement. They also lacked confidence in executing their knowledge after interpreting, reading and comparing financial products. Last but not the least, they did not fully understood that in order to remain staying informed, they need to have up-to-date information on the financial products. This is because of the fact that interest only would not make an individual financially capable. Sophistication of financial products and services nowadays accessed via digital media have made financial literacy even more relevant. It is essential for Malaysians to comprehend these products, services and channels in order to make the right financial decisions.

From the government point of view, there is a need for financial education to elevate financial literacy, promote responsible behaviour and rational attitudes among Malaysians to enhance their financial well-being. This can be supported when Financial Stability and Payment Systems Report (2018) revealed that several concerns among Malaysians which needs to be highlighted especially in level of financial knowledge, saving and budgeting, readiness for unexpected life events and retirement planning. Besides that, Credit Counselling and Debt Management or Agensi Kaunseling dan Pengurusan Kredit (AKPK) findings survey (AFBES'18) and Securities Commission Malaysia report (2018) also found that financial education plays a vital role in enhancing financial behaviour. With that, Malaysia National Strategy for Financial Literacy (2019 - 2023) empower Malaysians to have 3 strategic outcomes which are to save, manage and protect their money, plan ahead and ensure a sustainable future and lastly to protect oneself from fraud and financial scams.

In order to achieve those strategic outcomes, strategic priorities need to be conducted. First, nurturing values from young could impacted younger generation to be better and well equipped. Early awareness about financial literacy could prepare and educate youngsters to be a better individual particularly in personal finances. Second, accessibility to financial management information, tools and resources needs to be increased. Knowledge is a powerful tool that could enhance one's social status. Third, implementing positive behaviour among targeted groups that are in need of financial security. Combination of values and knowledge would inseminate individual's positive behaviour that will bring their confidence to the society especially vulnerable groups. Fourth, boosting a long term financial and retirement planning is important. Moral, knowledge and positive behaviour can escalate the passion to practice financial and retirement planning in a long term. Lastly, Malaysians need to build and safeguard their wealth after all the hard work. Cultivating wealth through financial and retirement planning with the help of availability and accessibility of financial information can build and safeguard wealth which can affect one's financial well-being.

\section{References}

Abdullah, N., Fazli, S. M., \& Arif, A. M. M. (2019). The Relationship between attitude towards money, financial literacy and debt management with young worker's financial wellbeing. Pertanika Journal of Social Sciences and Humanities, 27(1), 361-387.

AKPK Financial Behaviour Survey (AFBeS 2018). AKPK Financial Behaviour and State of Financial Well-being of Working Adults. Retrieved January 11, 2020 from https://www.akpk. org.my/sites/default/files/AKPK_Financial $\% 20$ Behaviour $\% 20$ and $\% 20$ State $\% 20$ of $\% 20$ Finanical $\% 20$ Well-being $\% 20$ of $\% 20$ Malaysian\%20Working\%20Adult.pdf

Alidaniah, N. A. R., Ahmad, S., Noor, M. A. M., \& Moi, M. R. (2017). Behaviour of household debt by race in Bandar Baru Bangi, Selangor. Geografia Malaysian Journal of Society and Space, 11(11), 110-119.

Al-Bahrani, A., Weathers, J., \& Patel, D. (2019). Racial differences in the returns to financial literacy education. Journal of Consumer Affairs, 53(2), 572-599.

Atkinson, A., McKay, S., Collard, S., \& Kempson, E. (2006). Levels of financial capability in the UK: Results of a baseline survey. London, UK: Financial Services Authority.

Banks, A. (2020). Is Financial Literacy the Answer to Closing America's Huge Racial Wealth Gap? Truth be Told. Retrieved March 30, 2020 from https://truthbetold.news/2020/01/isfinancial-literacy-the-answer-to-closing-americas-huge-racialwealth-gap/ 
Bharucha, J. P. (2017). Socio-Economic and Demographic Determinants of Indian Youth Financial Literacy: Determinants of Financial Literacy. International Journal of Asian Business and Information Management, 8(4), 15-28.

Dewees, S., \& Mottola, G. (2017). Race and financial capability in America: Understanding the Native American experience. Insights: Financial Capability. Retrieved June 30, 2019 from https://www.usfinancialcapability.org/downloads/NativeAmerican-Experience-Fin-Cap.pdf

Department of Statistics Malaysia. (2019). Current Population Estimates, Malaysia, 2018-2019. Retrieved February 25, 2020 fromhttps:/www.dosm.gov.my/v1_/index.php?r=column/ ctwoByCat\&parent_id=115\&menu_id=L 0 pheU 43 NWJwRWVSZklWdzQ4TlhUUT09

Do, H. T. H., Mai, C. N., Mai, A. N., Nguyen, N. D., Pham, T. N., Le, H. T. T., \& Vu, T. T. (2020). Impact of Vocational Training on Wages of Ethnic Minority Labors in Vietnam. Journal of Asian Finance, Economics, and Business, 7(6), 551-560. https://doi.org/10.13106/jafeb.2020.vol7.no6.551

Financial Stability and Payment Systems Report 2018. (2018). Market Conduct and Consumer Empowerment. Retrieved from: https://www.bnm.gov.my/files/publication/fsps/en/2018/ cp04.pdf

FINRA Investor Education Foundation. (2009). Financial Capability in the United States: National Survey. Executive Summary. Washington, DC. Accessed May 15, 2019 from: www.finrafoundation.org/capability

Jeyaram, S., \& Mustapha, M. (2015). Financial literacy and demographic factors. Journal of Technology Management and Business, 2(1), 1-8.

Johnson, E., \& Sherraden, M. S. (2007). From financial literacy to financial capability among youth. Journal of Sociology \& Social Welfare, 34(3), 119-146

Khan, O. (2008). Financial Inclusion and ethnicity, an agenda for research and policy action. Runnymede Reports, London.

Keeney, M. J., \& O’Donnell, N. (2009). Financial capability: New evidence for Ireland (No. 1/RT/09). Central Bank of Ireland.

Loke, Y. J. (2017). The influence of socio-demographic and financial knowledge factors on financial management practices of Malaysians. International Journal of Business and Society, 18(1), 33-50.

Lowies, B., Helliar, C., Lushington, K., \& Whait, R. (2019). The Financial Capability of older People. University of South Australia.

Lusardi, A., \& Oggero, N. (2017). Millennials and financial literacy: A global perspective. Global Financial Literacy Excellence Center. Retrieved from December 25, 2019 from https://www. gltfoundation.com/wp-content/uploads/2017/02/Millennialsand-Financial-Literacy-Policy-Brief.pdf

Malaysian National Strategy for Financial Literacy 2019-2023. (2020). Retrieved April 15, 2020 from: https://www.sc.com. my/resources/publications-and-research/fen
Mokhtar, N., Sabri, M. F., Catherine, S. F., \& Thinagaran, M. D. (2018). Profile and differences in financial literacy: Empirical evidence. Malaysian Journal of Consumer and Family Economics, 21, 164-185.

Nam, Y., Huang, J., \& Lee, E. J. (2016). Ethnic differences in financial outcomes among low-income older Asian Immigrants: A financial capability perspective. Journal of Community Practice, 24(4), 445-461. https://doi:10.1080/10705422.2016.1233474

Nguyen, T. A. N., \& Nguyen, K. M. (2020). Role of Financial Literacy and Peer Effect in Promotion of Financial Market Participation: Empirical Evidence in Vietnam. Journal of Asian Finance, Economics, and Business, 7(6), 1-8. https://doi. org/10.13106/jafeb.2020.vol7.no6.001

Ooko, R. A. (2017). Demographic and Socioeconomic Factors Influencing Financial Literacy among Employees of Deloitte Kenya. Doctoral dissertation, United States International University-Africa.

Organization for Economic Cooperation Development (OECD). (2005). Improving financial literacy: Analysis of issues and policies. Paris: OECD.

Pallant, J. (2020). SPSS survival manual: A step by step guide to data analysis using IBM SPSS. London, UK: Routledge.

Ranta, M., Punamäki, R-L., Chow,A., \& Salmela-Aro, K. (2019). The Economic Stress Model in Emerging Adulthood: The Role of Social Relationships and Financial Capability. Emerging Adulthood. https://doi.org/10.1177/2167696819893574

Rasheed, Z. (2020). COVID - 19 pandemic is testing world leaders. Who's stepping up? Retrieved July 31, 2020 from https://www. aljazeera.com/news/2020/04/covid-19-pandemic-testingworld-leaders-stepping-200402201221844.html

Sabri, M. F., Abdullah, N., Zenhendel, M., \& Ahmad, S. Y. (2018). Moderation effect of gender on financial literacy, money attitude, financial strains and financial capability. Malaysian Journal of Consumer and Family Economics, 20(1), 83-101.

Scott, J. K., Vu, N. N., Cheng, Y., \& Gibson, P. (2018). Financial capability: Literacy, behaviour, and distress. Financial Services Review, 27(4), 391-411.

Securities Commission Malaysia. (2018). Annual Report 2018. Retrieved June 30, 2019 from https://www.sc.com.my/api/ documentms/download.ashx?id=c8b45c99-da0e-4c2a-b392$08 \mathrm{a} 94 \mathrm{e} 7 \mathrm{c} 4 \mathrm{c} 1 \mathrm{c}$

Shiller, R. J. (2020). COVID - 19 has brought about a second pandemic: Financial anxiety. Retrieved August 29, 2020 from https://www.weforum.org/agenda/2020/04/pandemicscoronavirus-covid19-economics-finance-stock-market-crisis/

Tan, R. (2019). Vital to strengthen financial literacy, say experts. Retrieved August 21, 2019 from https:/www.thestar.com.my/ news/nation/2019/07/24/vital-to-strengthen-financial-literacysay-experts/

Taylor, M. (2011). Measuring financial capability and its determinants using survey data. Social Indicators Research, 102(2), 297-314. 
The World Bank. (2013, August). Financial Capability Surveys around the World: Why financial capability is important and how surveys can help. Retrieved from http://documents. worldbank.org/curated/en/693871468340173654/ pdf/807670WP0P14400Box0379820B00PUBLIC0.pdf

Wingfield, B. J. (2016). The Relationship between demographic factors and financial literacy among students at a South African University. Doctoral dissertation, University of Pretoria.

Xiao, J. J., Chen, C., \& Sun, L. (2015). Age differences in consumer financial capability. International Journal of Consumer Studies, 39, 387-395.

Xiao, J. J., Chen, C., \& Sun, L. (2014). Age and Financial Capability: Implication for Lifespan Financial Education. Consumer Interests Annual, 60, 1-10.

Xiao, J. J. (2016). Chapter 1: Consumer financial capability and wellbeing. In: J. J. Xiao (Ed.), Handbook of consumer finance. New York, NY: Springer.
Xiao, J. J., \& O’Neill, B. (2018). Propensity to plan, financial capability, and financial satisfaction. International Journal of Consumer Studies, 42(5), 501-512.

Xiao, J. J., \& O’Neill, B. (2016). Consumer financial education and financial capability. International Journal of Consumer Studies, 40(6), 712-721.

Yusof, S. A. (2019), Ethnic disparity in financial fragility in Malaysia, International Journal of Social Economics, 46(1), 31-46. https://doi.org/10.1108/IJSE-12-2017-0585

Yusof, S. A., Rokis, R. A., \& Jusoh, W. J. W. (2015). Financial fragility of urban households in Malaysia. Jurnal Ekonomi Malaysia, 49(1), 15-24.

Zulfaris, M. D., Mustafa, H., Mahussin, N., Alam, M. K., \& Daud, Z. M. (2020). Students and Money Management Behavior of a Malaysian Public University. Journal of Asian Finance, Economics and Business, 7(3), 245-251. https://doi. org/10.13106/jafeb.2020.vol7.no3.245 